\title{
Dietary Protein and Physical Activity Interventions to Support Muscle Maintenance in End-Stage Renal Disease Patients on Hemodialysis
}

\author{
Floris K. Hendriks ${ }^{1,2}{ }^{\circledR}$, Joey S.J. Smeets ${ }^{1}\left({ }^{1}\right.$, Frank M. van der Sande ${ }^{3}$, Jeroen P. Kooman ${ }^{2,3}$ and \\ Luc J.C. van Loon $1, *$ (i) \\ 1 Department of Human Biology, NUTRIM School of Nutrition and Translational Research in Metabolism, \\ Maastricht University Medical Centre+, P.O. Box 616, 6200 MD Maastricht, The Netherlands; \\ f.hendriks@maastrichtuniversity.nl (F.K.H.); joey.smeets@maastrichtuniversity.nl (J.S.J.S.) \\ 2 Department of Internal Medicine, NUTRIM School of Nutrition and Translational Research in Metabolism, \\ Maastricht University Medical Centre+, P.O. Box 616, 6200 MD Maastricht, The Netherlands; \\ jeroen.kooman@mumc.nl \\ 3 Division of Nephrology, Department of Internal Medicine, Maastricht University Medical Centre+, \\ P.O. Box 5800, 6202 AZ Maastricht, The Netherlands; f.vander.sande@mumc.nl \\ * Correspondence: L.vanLoon@maastrichtuniversity.nl; Tel.: +(31)-43-3881397
}

Received: 30 October 2019; Accepted: 3 December 2019; Published: 5 December 2019

\begin{abstract}
End-stage renal disease patients have insufficient renal clearance capacity left to adequately excrete metabolic waste products. Hemodialysis (HD) is often employed to partially replace renal clearance in these patients. However, skeletal muscle mass and strength start to decline at an accelerated rate after initiation of chronic HD therapy. An essential anabolic stimulus to allow muscle maintenance is dietary protein ingestion. Chronic HD patients generally fail to achieve recommended protein intake levels, in particular on dialysis days. Besides a low protein intake on dialysis days, the protein equivalent of a meal is extracted from the circulation during HD. Apart from protein ingestion, physical activity is essential to allow muscle maintenance. Unfortunately, most chronic HD patients have a sedentary lifestyle. Yet, physical activity and nutritional interventions to support muscle maintenance are generally not implemented in routine patient care. To support muscle maintenance in chronic HD patients, quantity and timing of protein intake should be optimized, in particular throughout dialysis days. Furthermore, implementing physical activity either during or between HD sessions may improve the muscle protein synthetic response to protein ingestion. A well-orchestrated combination of physical activity and nutritional interventions will be instrumental to preserve muscle mass in chronic HD patients.
\end{abstract}

Keywords: muscle wasting; exercise; nutrition; kidney disease

\section{Introduction}

Chronic kidney disease (CKD) is currently a public health problem with a global prevalence of $10 \%$ and the cause of approximately 33 million disability-adjusted life-years worldwide [1,2]. Development and progression of CKD are associated with the age-related decline in renal function, especially in individuals with hypertension and diabetes mellitus [3-5]. Therefore, the rapid ageing of our population is expected to further increase prevalence of CKD and its progression to end-stage renal disease (ESRD) [6,7]. The glomerular filtration rate in ESRD patients is below $15 \mathrm{~mL} / \mathrm{min} / 1.73 \mathrm{~m}^{2}$ and insufficient to adequately remove metabolic waste products and fluids from the body [8,9]. Due to the accumulation of metabolic waste products in their body, ESRD patients experience phenotypic changes that resemble the ageing process, with a progressive loss of skeletal muscle mass and strength [10]. 
To prevent lethal consequences of metabolic waste product accumulation in ESRD patients, hemodialysis (HD) can be used to partially replace renal solute removal [11]. Over the past decades, survival of patients undergoing HD has improved substantially $[12,13]$. However, prevention of the adverse effects of HD on body composition has made less progression. After initiation of chronic hemodialysis (CHD) therapy, the age-related loss of skeletal muscle mass and strength accelerates and patients typically develop impairments in physical function [14-17]. Protein-energy wasting, a severe state of malnutrition, is observed in $28 \%-54 \%$ of CHD patients [18,19]. Loss of skeletal muscle mass and strength predisposes CHD patients to frailty and substantially reduces their quality of life [20]. Furthermore, the decline in skeletal muscle mass and strength is associated with higher hospitalization and mortality rates in CHD patients [20-22]. As the duration of CHD treatment is associated with its detrimental effects on body composition, the improved survival rate of CHD patients will generate new challenges for healthcare [14]. This emphasizes the need to understand and counteract skeletal muscle mass and strength loss in CHD patients.

\section{Muscle Maintenance}

Skeletal muscle mass is regulated through a dynamic balance between continuous synthesis and breakdown of muscle proteins. The muscle protein pool has shown to possess a turnover rate of $1 \%-2 \%$ per day, allowing skeletal muscle tissue to adapt to circumstances such as changes in physical activity pattern (e.g., muscle hypertrophy following resistance-type exercise training) [23]. Ingesting several protein-containing meals throughout the day results in a sinusoidal pattern of subsequent increases and decreases in skeletal muscle protein synthesis and breakdown rates [24]. Skeletal muscle protein synthesis rates are high during post-prandial periods and low during post-absorptive periods, whilst skeletal muscle protein breakdown rates follow a reverse pattern. Muscle maintenance is achieved when skeletal muscle protein synthesis rates equal skeletal muscle protein breakdown rates over a given period.

Protein ingestion is an essential requirement to maintain skeletal muscle mass. After consumption, dietary protein is absorbed as amino acids in the intestine, with a large fraction being subsequently released into the circulation [25]. The release of amino acids into the circulation following protein ingestion elevates plasma amino acid concentrations for a post-prandial period of up to $5 \mathrm{~h}$ [26]. These circulating plasma amino acids serve as precursors for de novo synthesis of muscle protein [27]. However, amino acids are more than simply building blocks for muscle protein synthesis, as they can function as signaling molecules. The post-prandial increase in plasma essential amino acid concentrations, and leucine in particular, stimulates anabolic signaling through several molecular pathways, such as the mammalian target of rapamycin complex 1 (mTORC1) pathway [28,29]. This post-prandial anabolic signaling increases skeletal muscle protein synthesis rates and inhibits proteolysis, allowing net muscle protein accretion [27].

Muscle loss can be attributed both to an increase in muscle protein breakdown as well as to a decline in muscle protein synthesis rates. Previous work has reported increased muscle proteolysis in CHD patients due to inflammation, metabolic acidosis, and the dialysis procedure itself [30-33]. Furthermore, it has been suggested that the muscle protein synthetic response to feeding is impaired in patients with CKD [34]. Whereas a maximal post-prandial muscle protein synthetic response has been reported after ingesting up to $20 \mathrm{~g}$ of a high-quality protein in healthy young adults, a lesser response has been observed in older individuals [27,35,36]. More recently, van Vliet et al. were unable to detect a measurable increase in skeletal muscle protein synthesis rates in CHD patients following ingestion of a meal containing $20 \mathrm{~g}$ protein [37]. The latter suggests that CHD patients suffer from a blunted muscle protein synthetic response to feeding, a phenomenon that has been coined anabolic resistance. In healthy elderly individuals, it has been shown that the anabolic resistance of skeletal muscle tissue can be overcome through ingesting a greater amount of protein (at least $30 \mathrm{~g}$ of a high-quality protein) [38] and/or performing a bout of resistance-type exercise prior to feeding [39]. When tailored 
specific to CHD patients, these anabolic strategies may prove essential to attenuate or even prevent the accelerated loss of skeletal muscle mass and strength in ESRD patients undergoing HD.

\section{Dietary Protein Intake in ESRD Patients on HD}

For healthy young adults, the recommended dietary protein intake to achieve a net balance between muscle protein synthesis and breakdown rates has been set at $0.8 \mathrm{~g}$ protein $/ \mathrm{kg}$ body weight/day by the World Health Organization [40,41]. This level of protein intake may not be sufficient to support muscle maintenance in CHD patients. According to the National Kidney Foundation K/DOQI Clinical Practice Guidelines, these patients are recommended to ingest $>1.2 \mathrm{~g}$ protein $/ \mathrm{kg}$ body weight $/$ day [42-45]. However, CHD patients generally do not meet this recommended level of protein intake. Previous studies in this population have observed a dietary protein intake of $0.9-1.0 \mathrm{~g}$ protein $/ \mathrm{kg}$ body weight/day [46-51]. Especially on dialysis days, factors such as time constraints and reduced appetite make it difficult for patients to consume ample dietary protein [52]. As a result, dietary protein intake in CHD patients has been reported to be $\sim 0.8 \mathrm{~g}$ protein $/ \mathrm{kg}$ body weight on dialysis days compared to $\sim 1.0 \mathrm{~g}$ protein/kg body weight on non-dialysis days [50].

In addition to low protein intake, another factor compromises plasma amino acid availability on dialysis days. During HD, both metabolic waste products as well as circulating amino acids are able to diffuse through the semipermeable dialysis membrane [11]. The diffusion into the dialysate results in a considerable extraction of circulating amino acids throughout HD [30,53-56]. We have recently shown that during a single HD session, $\sim 12 \mathrm{~g}$ amino acids are extracted from the circulation in CHD patients who ingest their habitual diet during HD [57]. This amount equals the quantity of amino acids that is released into the circulation following ingestion of a typical meal (containing 20-25 g protein). Loss of circulating amino acids causes a significant decline of plasma amino acid concentrations throughout HD [55,57]. Moreover, Ikizler et al. showed that in fasting CHD patients, plasma amino acid concentrations remain low for at least $2 \mathrm{~h}$ after cessation of HD [30]. The HD-induced decline in plasma amino acid concentrations has been shown to cause substantial catabolism of skeletal muscle tissue in fasted CHD patients $[58,59]$. The continuous extraction of amino acids throughout HD stimulates skeletal muscle tissue to release amino acids into the circulation $[60,61]$. This homeostatic process attenuates the decline in plasma amino acid concentrations and may prevent subsequent detrimental effects on organs that are necessary to sustain life [62]. In addition, the decline in plasma amino acid concentrations reduces the availability of precursors for de novo synthesis of muscle proteins during and following HD. To allow a muscle protein synthetic response during this period, the extraction of circulating amino acids should be compensated for through amino acid and/or protein administration.

Provision of protein-rich nutrition during HD is often recommended to increase dietary protein intake on dialysis days [63-66]. Ingestion of 40-60 g protein has been shown to prevent the HD-induced decline in plasma amino acid concentrations in multiple studies $[58,59,67,68]$. Furthermore, Pupim et al. demonstrated that ingestion of $57 \mathrm{~g}$ protein resulted in a positive forearm amino acid balance throughout HD [58]. Thus, HD-associated skeletal muscle catabolism may be prevented through ingestion of sufficient protein during HD. Several studies have also observed long-term beneficial effects of protein supplementation during HD, such as an increase in lean body mass, improvement in physical function, and decrease in mortality [69-71]. However, data from our lab [57] and others [56,67] indicate that protein ingestion during HD is also accompanied by an increase in amino acid extraction, presumably due to a higher subsequent plasma-dialysate diffusion gradient (Figure 1). Due to this extraction following protein ingestion during $\mathrm{HD}$, less amino acids become available to stimulate muscle protein synthesis rates and serve as precursors for de novo synthesis of muscle protein. Considering the anabolic resistance of skeletal muscle tissue that is also present in this population, CHD patients will need to ingest well above $20 \mathrm{~g}$ high-quality protein during $\mathrm{HD}$ to allow a post-prandial increase in skeletal muscle protein synthesis and an inhibition of proteolysis. 


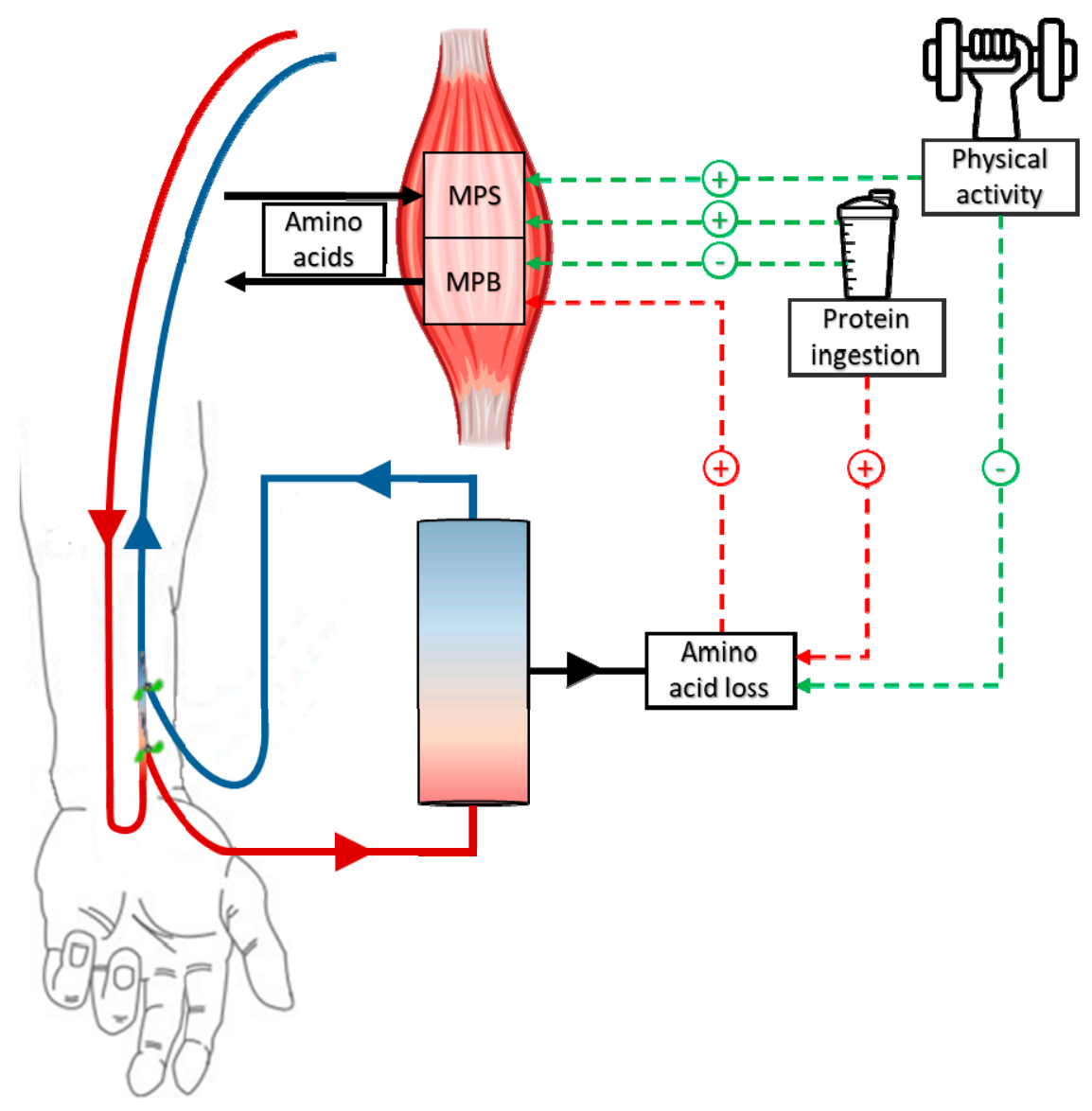

Figure 1. Conceptual overview of the effects of hemodialysis, protein ingestion, and physical activity on the muscle protein synthetic and proteolytic response. The extraction of amino acids during hemodialysis (HD) stimulates muscle protein breakdown (MPB) rates due to decreased plasma amino acid concentrations. Protein ingestion can maintain, or even increase, plasma amino acid concentrations throughout HD, which increases muscle protein synthesis (MPS) rates, while it may attenuate the HD-induced increase in MPB rates. However, elevated plasma amino acid concentrations also increase the amount of amino acids that are extracted during HD. Physical activity before or during HD may increase the use of plasma amino acids for de novo MPS, and thereby reduce the amount of amino acids that are extracted from the circulation during HD. Dashed lines in green represent processes that support muscle maintenance, whereas dashed lines in red represent processes that compromise muscle maintenance.

However, high quality (animal-derived) protein is rich in phosphorous [72]. In CHD patients, an increased dietary protein intake may lead to hyperphosphatemia or the need for phosphate binders. Furthermore, it has been suggested that an increased dietary protein intake in CHD patients provides more uremic toxin precursors and leads to higher uremic solute concentrations between HD sessions [73]. Recently, our laboratory has shown that the ingestion of branched-chain ketoacids, which contain no phosphorous or nitrogen, significantly stimulates skeletal muscle protein synthesis rates in healthy elderly individuals [74]. Ketoacid supplementation in CKD patients has been shown to reduce the generation of toxic metabolic waste products, while maintaining a good nutritional status [75]. However, it remains to be established whether ketoacid supplementation could support muscle maintenance in CHD patients.

\section{Physical Activity in ESRD Patients on HD}

Another key component for muscle maintenance is physical activity. Physical activity and exercise stimulate skeletal muscle protein synthesis rates, with post-absorptive muscle protein synthesis rates 
being elevated for up to 24 or even $48 \mathrm{~h}$ [76,77]. Furthermore, physical activity performed prior to food intake augments the post-prandial muscle protein synthetic response to feeding [78-81]. In contrast, a decline in physical activity reduces the muscle protein synthetic response to feeding [82-84]. In other words, whereas physical activity makes skeletal muscle tissue more sensitive to the anabolic properties of amino acids, muscle disuse leads to anabolic resistance of skeletal muscle tissue [85]. In support, daily exercise has been shown to increase skeletal muscle protein synthesis rates throughout the day [86], while a decline in physical activity has been shown to lower daily muscle protein synthesis rates [87]. Consequently, ample physical activity has been associated with a reduced age-related loss of muscle mass and strength $[88,89]$, whereas a decline in the level of physical activity (e.g., during bed rest or limb immobilization) has been shown to induce a rapid decline in muscle mass and strength $[90,91]$.

According to the Physical Activity Guidelines for Americans, patients with chronic diseases should follow the key physical activity guidelines for healthy adults to achieve substantial health benefits [92]. These guidelines recommend patients to perform at least 150-300 min per week of moderate-intensity aerobic exercise, $75-150 \mathrm{~min}$ of vigorous-intensity aerobic exercise per week, or an equivalent combination of both. In addition, muscle-strengthening activities that involve all major muscle groups should be performed at least twice per week. However, these guidelines do not contain specific recommendations for CHD patients. The Renal Association Clinical Practice Guideline on Hemodialysis recommends that all CHD patients without contraindication should perform at least $30 \mathrm{~min}$ of supervised moderate-intensity exercise during every dialysis session [93]. In addition, the guideline states that CHD patients should be encouraged to undertake physical activity on non-dialysis days. In line with this recommendation, it has recently been suggested that mortality rates are reduced in CHD patients who perform at least 4000 steps on non-dialysis days [94].

However, CHD patients typically adopt a sedentary lifestyle and spend less time being physically active than healthy adults $[95,96]$. In the United States, almost $50 \%$ of CHD patients perform exercise once or less than once per week [96]. A HD session represents a long (3-4 h) sedentary period, which often hinders CHD patients to engage in physical activity and, as such, dialysis treatments contribute to the lower physical activity levels [97,98]. Gomes et al. observed that CHD patients took $4362 \pm 2084$ and $7007 \pm 3437$ steps on dialysis and non-dialysis days, respectively, compared to $8792 \pm 2870$ steps taken by age-matched healthy controls [98]. The low habitual physical activity level in these patients is another key factor responsible for the accelerated loss of muscle mass and strength in CHD patients [17]. Interventions in CHD patients targeted to preserve or even increase muscle mass should not only provide nutritional support but also increase physical activity levels to maximize their impact.

\section{Interventions to Support Muscle Maintenance in ESRD Patients on HD}

Physical activity interventions for CHD patients may implement exercise during HD (intradialytic) or between HD sessions (interdialytic). A recent meta-analysis by Clarckson et al. reported no differences in the efficacy of intradialytic when compared with interdialytic exercise on improvements of physical function in CHD patients [99]. Due to exercise intolerance, CHD patients typically show low adherence and poor compliance to long-term unsupervised physical activity intervention programs [100]. HD sessions represent an opportunity to integrate supervised physical activity in the weekly routine of CHD patients. Intradialytic physical activity is considered safe and shows greater adherence rates than interdialytic physical activity [100-102]. Furthermore, supervision of intradialytic exercise sessions provides the opportunity to prescribe a patient-specific and progressive exercise program. Physical activity during HD has some limitations compared to interdialytic physical activity, such as constrains regarding exercise intensity and upper limb exercises. On the other hand, intradialytic physical activity provides distraction for CHD patients during their treatment and has been shown to improve their quality of life [101]. Therefore, we would advocate the implementation of an intradialytic exercise program in lifestyle interventions designed for (sedentary) CHD patients.

In addition to timing, the type of exercise is an important determinant of its potential to support muscle maintenance. Resistance-type exercise training is considered most potent to augment muscle 
mass and strength. In healthy adults, resistance-type exercise training has been shown to induce a robust increase in both skeletal muscle mass as well as strength [103-105]. Furthermore, resistance-type exercise also sensitizes skeletal muscle tissue to the anabolic properties of amino acids and, as such, increases the post-prandial muscle protein synthetic response to feeding [78,79,81]. In support, it has been reported that a single bout of resistance-type exercise performed prior to HD increases amino acid uptake by muscle tissue following intradialytic protein ingestion [106]. Intradialytic resistance-type exercise programs have shown to increase skeletal muscle strength, thereby improving physical function outcome measures such as the 6-min walk test [99,107-110]. In a systematic review of nine trials that assessed progressive resistance-type exercise training in ESRD patients on HD, Chan and Cheema concluded that resistance-type exercise training can effectively induce regional skeletal muscle hypertrophy [111]. However, due to inconsistent results of previous studies [69,112-118], it remains unclear whether resistance-type exercise can increase skeletal muscle mass on a whole-body level in CHD patients.

Protein ingestion during recovery from resistance-type exercise is required to achieve a positive net protein balance and, as such, to allow net muscle protein accretion [76]. Due to practical matters, the majority of studies that assessed the impact of resistance-type exercise training in CHD patients implemented their training sessions before or during HD [119]. As circulating amino acids are extracted during HD, recovery from those exercise sessions typically occurred during conditions of reduced amino acid availability. This may have attenuated the anabolic effects of the exercise training programs. Furthermore, the combination of amino acid extraction during HD and the anabolic resistance of skeletal muscle tissue in CHD patients likely increases the amount of protein that is required following intradialytic resistance-type exercise. We suggest that at least $30 \mathrm{~g}$ protein should be provided to CHD patients during recovery from resistance-type exercise performed immediately prior or during HD to allow a muscle protein synthetic response.

Besides protein ingestion during recovery from exercise, it has been advocated that every main meal (breakfast, lunch, and dinner) should contain $20 \mathrm{~g}$ high-quality protein to optimally stimulate muscle protein synthesis rates throughout the day $[120,121]$. We suggest that CHD patients should ingest well above $20 \mathrm{~g}$ high-quality protein per main meal to compensate for the blunted muscle protein synthetic response to feeding, recognizing that additional measures to prevent hyperphosphatemia might be necessary. In addition, ingesting a protein-rich snack prior to sleep, especially on training days, may further support muscle mass maintenance [24]. Though the impact of these nutritional strategies has not been assessed in CHD patients, they would likely be supplemental in the prevention of protein malnutrition in this population. Effectiveness of any nutritional intervention largely depends on long-term adherence and compliance. However, adherence to dietary interventions in CHD patients is often poor due to barriers such as dialysis time, motivation, and lack of social support [122]. Therefore, CHD patients should be advised on protein options that are easy to prepare, convenient to consume, and have an acceptable taste.

A well-orchestrated lifestyle intervention program combining exercise and nutritional interventions for CHD patients is required to attenuate or even prevent the loss of muscle mass, strength, and functional capacity in this population. For such a multimodal interventional approach to be effective, a (more) personalized supervision of CHD patients provided by a team of healthcare specialists with physical activity and nutritional expertise is required. A close collaboration between nephrologists, physical therapists, and dietitians in both research and clinical care will be essential to improve the health and well-being of the growing number of CHD patients.

\section{Conclusions}

The gradual loss of skeletal muscle mass in CHD patients accelerates after initiation of intermittent HD treatment. Muscle protein breakdown rates in CHD patients are increased, while muscle protein synthesis rates fail to match this increase due to insufficient protein ingestion, amino acid extraction during HD, and the prevalence of anabolic resistance. Protein intake of CHD patients should be increased 
on dialysis days to compensate for extraction of circulating amino acids during $\mathrm{HD}$ and to compensate for the blunted muscle protein synthetic response to feeding in these patients. Implementing structured physical activity in the daily routine of CHD patients represents a feasible strategy to increase the skeletal muscle protein synthetic response to protein ingestion and, as such, to alleviate anabolic resistance. More insight in the impact of protein ingestion and exercise in CHD patients on both dialysis as well as non-dialysis days is required to develop more effective nutritional and exercise intervention programs that can attenuate or even prevent muscle loss in CHD patients.

Author Contributions: Writing—original draft preparation, F.K.H. and L.J.C.v.L.; writing—review and editing, J.S.J.S., F.M.v.d.S., and J.P.K., All authors read and approved the final manuscript.

Funding: This work was supported by a grant from the NUTRIM NWO Graduate Programme.

Conflicts of Interest: The authors declare no conflicts of interest. The funders had no role in the writing of the manuscript or in the decision to publish.

\section{References}

1. Mortality, G.B.D. Catrgory: Causes of Death. Global, regional, and national life expectancy, all-cause mortality, and cause-specific mortality for 249 causes of death, 1980-2015: A systematic analysis for the Global Burden of Disease Study 2015. Lancet 2016, 388, 1459-1544. [CrossRef]

2. Dalys, G.B.D.; Collaborators, H.; Murray, C.J.; Barber, R.M.; Foreman, K.J.; Abbasoglu Ozgoren, A.; Abd-Allah, F.; Abera, S.F.; Aboyans, V.; Abraham, J.P.; et al. Global, regional, and national disability-adjusted life years (DALYs) for 306 diseases and injuries and healthy life expectancy (HALE) for 188 countries, 1990-2013: Quantifying the epidemiological transition. Lancet 2015, 386, 2145-2191. [CrossRef]

3. Gansevoort, R.T.; Correa-Rotter, R.; Hemmelgarn, B.R.; Jafar, T.H.; Heerspink, H.J.L.; Mann, J.F.; Matsushita, K.; Wen, C.P. Chronic kidney disease and cardiovascular risk: Epidemiology, mechanisms, and prevention. Lancet 2013, 382, 339-352. [CrossRef]

4. Hill, N.R.; Fatoba, S.T.; Oke, J.L.; Hirst, J.A.; O'Callaghan, C.A.; Lasserson, D.S.; Hobbs, F.D. Global Prevalence of Chronic Kidney Disease-A Systematic Review and Meta-Analysis. PLoS ONE 2016, 11, e0158765. [CrossRef] [PubMed]

5. Webster, A.C.; Nagler, E.V.; Morton, R.L.; Masson, P. Chronic Kidney Disease. Lancet 2017, 389, 1238-1252. [CrossRef]

6. Van Oostrom, S.H.; Gijsen, R.; Stirbu, I.; Korevaar, J.C.; Schellevis, F.G.; Picavet, H.S.; Hoeymans, N. Time Trends in Prevalence of Chronic Diseases and Multimorbidity Not Only due to Aging: Data from General Practices and Health Surveys. PLoS ONE 2016, 11, e0160264. [CrossRef]

7. Tonelli, M.; Riella, M. Chronic kidney disease and the ageing population. Nephron Clin. Pract. 2014, 128, 319-322. [CrossRef]

8. Levey, A.S.; Eckardt, K.U.; Tsukamoto, Y.; Levin, A.; Coresh, J.; Rossert, J.; De Zeeuw, D.; Hostetter, T.H.; Lameire, N.; Eknoyan, G. Definition and classification of chronic kidney disease: A position statement from Kidney Disease: Improving Global Outcomes (KDIGO). Kidney Int. 2005, 67, 2089-2100. [CrossRef]

9. Agarwal, R. Defining end-stage renal disease in clinical trials: A framework for adjudication. Nephrol. Dial. Transplant. 2016, 31, 864-867. [CrossRef]

10. Kooman, J.P.; Kotanko, P.; Schols, A.M.; Shiels, P.G.; Stenvinkel, P. Chronic kidney disease and premature ageing. Nat. Rev. Nephrol. 2014, 10, 732-742. [CrossRef]

11. Himmelfarb, J.; Ikizler, T.A. Hemodialysis. N. Engl. J. Med. 2010, 363, 1833-1845. [CrossRef] [PubMed]

12. Fleming, G.M. Renal replacement therapy review. Organogenesis 2014, 7, 2-12. [CrossRef] [PubMed]

13. Marshall, M.R.; Polkinghorne, K.R.; Kerr, P.G.; Agar, J.W.; Hawley, C.M.; McDonald, S.P. Temporal Changes in Mortality Risk by Dialysis Modality in the Australian and New Zealand Dialysis Population. Am. J. Kidney Dis. 2015, 66, 489-498. [CrossRef] [PubMed]

14. Marcelli, D.; Brand, K.; Ponce, P.; Milkowski, A.; Marelli, C.; Ok, E.; Merello Godino, J.I.; Gurevich, K.; Jirka, T.; Rosenberger, J.; et al. Longitudinal Changes in Body Composition in Patients After Initiation of Hemodialysis Therapy: Results from an International Cohort. J. Ren. Nutr. 2016, 26, 72-80. [CrossRef] [PubMed] 
15. Spiegel, B.M.; Melmed, G.; Robbins, S.; Esrailian, E. Biomarkers and health-related quality of life in end-stage renal disease: A systematic review. Clin. J. Am. Soc. Nephrol. 2008, 3, 1759-1768. [CrossRef]

16. Kurella Tamura, M.; Covinsky, K.E.; Chertow, G.M.; Yaffe, K.; Landefeld, C.S.; McCulloch, C.E. Functional status of elderly adults before and after initiation of dialysis. N. Engl. J. Med. 2009, 361, 1539-1547. [CrossRef]

17. Johansen, K.L.; Shubert, T.; Doyle, J.; Soher, B.; Sakkas, G.K.; Kent-Braun, J.A. Muscle atrophy in patients receiving hemodialysis: Effects on muscle strength, muscle quality, and physical function. Kidney Int. 2003, 63, 291-297. [CrossRef]

18. Carrero, J.J.; Thomas, F.; Nagy, K.; Arogundade, F.; Avesani, C.M.; Chan, M.; Chmielewski, M.; Cordeiro, A.C.; Espinosa-Cuevas, A.; Fiaccadori, E.; et al. Global Prevalence of Protein-Energy Wasting in Kidney Disease: A Meta-analysis of Contemporary Observational Studies From the International Society of Renal Nutrition and Metabolism. J. Ren. Nutr. 2018, 28, 380-392. [CrossRef]

19. Fouque, D.; Kalantar-Zadeh, K.; Kopple, J.; Cano, N.; Chauveau, P.; Cuppari, L.; Franch, H.; Guarnieri, G.; Ikizler, T.A.; Kaysen, G.; et al. A proposed nomenclature and diagnostic criteria for protein-energy wasting in acute and chronic kidney disease. Kidney Int. 2008, 73, 391-398. [CrossRef]

20. Broers, N.J.; Usvyat, L.A.; Kooman, J.P.; van der Sande, F.M.; Lacson, E., Jr.; Kotanko, P.; Maddux, F.W. Quality of Life in Dialysis Patients: A Retrospective Cohort Study. Nephron 2015, 130, 105-112. [CrossRef]

21. Isoyama, N.; Qureshi, A.R.; Avesani, C.M.; Lindholm, B.; Barany, P.; Heimburger, O.; Cederholm, T.; Stenvinkel, P.; Carrero, J.J. Comparative associations of muscle mass and muscle strength with mortality in dialysis patients. Clin. J. Am. Soc. Nephrol. 2014, 9, 1720-1728. [CrossRef] [PubMed]

22. Borges, M.C.; Vogt, B.P.; Martin, L.C.; Caramori, J.C. Malnutrition Inflammation Score cut-off predicting mortality in maintenance hemodialysis patients. Clin. Nutr. ESPEN 2017, 17, 63-67. [CrossRef] [PubMed]

23. Mamerow, M.M.; Mettler, J.A.; English, K.L.; Casperson, S.L.; Arentson-Lantz, E.; Sheffield-Moore, M.; Layman, D.K.; Paddon-Jones, D. Dietary protein distribution positively influences 24-h muscle protein synthesis in healthy adults. J. Nutr. 2014, 144, 876-880. [CrossRef] [PubMed]

24. Trommelen, J.; van Loon, L.J. Pre-Sleep Protein Ingestion to Improve the Skeletal Muscle Adaptive Response to Exercise Training. Nutrients 2016, 8, 763. [CrossRef] [PubMed]

25. Groen, B.B.; Horstman, A.M.; Hamer, H.M.; de Haan, M.; van Kranenburg, J.; Bierau, J.; Poeze, M.; Wodzig, W.K.; Rasmussen, B.B.; van Loon, L.J. Post-Prandial Protein Handling: You Are What You Just Ate. PLoS ONE 2015, 10, e0141582. [CrossRef] [PubMed]

26. Kouw, I.W.; Gorissen, S.H.; Burd, N.A.; Cermak, N.M.; Gijsen, A.P.; van Kranenburg, J.; van Loon, L.J. Postprandial Protein Handling Is Not Impaired in Type 2 Diabetes Patients When Compared with Normoglycemic Controls. J. Clin. Endocrinol. Metab. 2015, 100, 3103-3111. [CrossRef]

27. Wall, B.T.; Gorissen, S.H.; Pennings, B.; Koopman, R.; Groen, B.B.; Verdijk, L.B.; van Loon, L.J. Aging Is Accompanied by a Blunted Muscle Protein Synthetic Response to Protein Ingestion. PLoS ONE 2015, 10, e0140903. [CrossRef]

28. Bohe, J.; Low, A.; Wolfe, R.R.; Rennie, M.J. Human muscle protein synthesis is modulated by extracellular, not intramuscular amino acid availability: A dose-response study. J. Physiol. 2003, 552, 315-324. [CrossRef]

29. Rieu, I.; Balage, M.; Sornet, C.; Giraudet, C.; Pujos, E.; Grizard, J.; Mosoni, L.; Dardevet, D. Leucine supplementation improves muscle protein synthesis in elderly men independently of hyperaminoacidaemia. J. Physiol. 2006, 575, 305-315. [CrossRef]

30. Ikizler, T.A.; Pupim, L.B.; Brouillette, J.R.; Levenhagen, D.K.; Farmer, K.; Hakim, R.M.; Flakoll, P.J. Hemodialysis stimulates muscle and whole body protein loss and alters substrate oxidation. Am. J. Physiol. Endocrinol. Metab. 2002, 282, E107-E116. [CrossRef]

31. Wang, X.H.; Mitch, W.E. Mechanisms of muscle wasting in chronic kidney disease. Nat. Rev. Nephrol. 2014, 10, 504-516. [CrossRef] [PubMed]

32. Kooman, J.P.; Dekker, M.J.; Usvyat, L.A.; Kotanko, P.; van der Sande, F.M.; Schalkwijk, C.G.; Shiels, P.G.; Stenvinkel, P. Inflammation and premature aging in advanced chronic kidney disease. Am. J. Physiol. Ren. Physiol. 2017, 313, F938-F950. [CrossRef] [PubMed]

33. Lofberg, E.; Gutierrez, A.; Anderstam, B.; Wernerman, J.; Bergstrom, J.; Price, S.R.; Mitch, W.E.; Alvestrand, A. Effect of bicarbonate on muscle protein in patients receiving hemodialysis. Am. J. Kidney Dis. 2006, 48, 419-429. [CrossRef] [PubMed]

34. Garibotto, G. Muscle amino acid metabolism and the control of muscle protein turnover in patients with chronic renal failure. Nutrition 1999, 15, 145-155. [CrossRef] 
35. Cuthbertson, D.; Smith, K.; Babraj, J.; Leese, G.; Waddell, T.; Atherton, P.; Wackerhage, H.; Taylor, P.M.; Rennie, M.J. Anabolic signaling deficits underlie amino acid resistance of wasting, aging muscle. FASEB J. 2005, 19, 422-424. [CrossRef]

36. Morton, R.W.; McGlory, C.; Phillips, S.M. Nutritional interventions to augment resistance training-induced skeletal muscle hypertrophy. Front. Physiol. 2015, 6, 245. [CrossRef]

37. Van Vliet, S.; Skinner, S.K.; Beals, J.W.; Pagni, B.A.; Fang, H.Y.; Ulanov, A.V.; Li, Z.; Paluska, S.A.; Mazzulla, M.; West, D.W.D.; et al. Dysregulated Handling of Dietary Protein and Muscle Protein Synthesis After Mixed-Meal Ingestion in Maintenance Hemodialysis Patients. Kidney Int. Rep. 2018, 3, 1403-1415. [CrossRef]

38. Pennings, B.; Groen, B.; de Lange, A.; Gijsen, A.P.; Zorenc, A.H.; Senden, J.M.; van Loon, L.J. Amino acid absorption and subsequent muscle protein accretion following graded intakes of whey protein in elderly men. Am. J. Physiol. Endocrinol. Metab. 2012, 302, E992-E999. [CrossRef]

39. Yang, Y.; Breen, L.; Burd, N.A.; Hector, A.J.; Churchward-Venne, T.A.; Josse, A.R.; Tarnopolsky, M.A.; Phillips, S.M. Resistance exercise enhances myofibrillar protein synthesis with graded intakes of whey protein in older men. Br. J. Nutr. 2012, 108, 1780-1788. [CrossRef]

40. World Health Organization; Food and Agriculture Organization of the United Nations; United Nations University. Protein and Amino Acid Requirements in Human Nutrition; World Health Organization: Geneva, Switzerland, 2007.

41. Rand, W.M.; Pellett, P.L.; Young, V.R. Meta-analysis of nitrogen balance studies for estimating protein requirements in healthy adults. Am. J. Clin. Nutr. 2003, 77, 109-127. [CrossRef] [PubMed]

42. Borah, M.F.; Schoenfeld, P.Y.; Gotch, F.A.; Sargent, J.A.; Wolfson, M.; Humphreys, M.H. Nitrogen balance during intermittent dialysis therapy of uremia. Kidney Int. 1978, 14, 491-500. [CrossRef] [PubMed]

43. Rao, M.; Sharma, M.; Juneja, R.; Jacob, S.; Jacob, C.K. Calculated nitrogen balance in hemodialysis patients: Influence of protein intake. Kidney Int. 2000, 58, 336-345. [CrossRef] [PubMed]

44. Kopple, J.D. National Kidney Foundation K/DOQI Clinical Practice Guidelines for Nutrition in Chronic Renal Failure. Am. J. Kidney Dis. 2001, 37, S66-S70. [CrossRef] [PubMed]

45. Fouque, D.; Vennegoor, M.; ter Wee, P.; Wanner, C.; Basci, A.; Canaud, B.; Haage, P.; Konner, K.; Kooman, J.; Martin-Malo, A.; et al. EBPG guideline on nutrition. Nephrol. Dial. Transplant. 2007, 22 (Suppl. 2), ii45-ii87. [CrossRef]

46. Burrowes, J.D.; Larive, B.; Cockram, D.B.; Dwyer, J.; Kusek, J.W.; McLeroy, S.; Poole, D.; Rocco, M.V.; Hemodialysis Study, G. Effects of dietary intake, appetite, and eating habits on dialysis and non-dialysis treatment days in hemodialysis patients: Cross-sectional results from the HEMO study. J. Ren. Nutr. 2003, 13, 191-198. [CrossRef]

47. Kalantar-Zadeh, K.; Kopple, J.D.; Deepak, S.; Block, D.; Block, G. Food intake characteristics of hemodialysis patients as obtained by food frequency questionnaire. J. Ren. Nutr. 2002, 12, 17-31. [CrossRef]

48. Lorenzo, V.; de Bonis, E.; Rufino, M.; Hernandez, D.; Rebollo, S.G.; Rodriguez, A.P.; Torres, A. Caloric rather than protein deficiency predominates in stable chronic haemodialysis patients. Nephrol. Dial. Transplant. 1995, 10, 1885-1889.

49. Wolfson, M.; Strong, C.J.; Minturn, D.; Gray, D.K.; Kopple, J.D. Nutritional status and lymphocyte function in maintenance hemodialysis patients. Am. J. Clin. Nutr. 1984, 39, 547-555. [CrossRef]

50. Martins, A.M.; Dias Rodrigues, J.C.; de Oliveira Santin, F.G.; Barbosa Brito Fdos, S.; Bello Moreira, A.S.; Lourenco, R.A.; Avesani, C.M. Food intake assessment of elderly patients on hemodialysis. J. Ren. Nutr. 2015, 25, 321-326. [CrossRef]

51. Bossola, M.; Leo, A.; Viola, A.; Carlomagno, G.; Monteburini, T.; Cenerelli, S.; Santarelli, S.; Boggi, R.; Miggiano, G.; Vulpio, C.; et al. Dietary intake of macronutrients and fiber in Mediterranean patients on chronic hemodialysis. J. Nephrol. 2013, 26, 912-918. [CrossRef] [PubMed]

52. Clark-Cutaia, M.N.; Sevick, M.A.; Thurheimer-Cacciotti, J.; Hoffman, L.A.; Snetselaar, L.; Burke, L.E.; Zickmund, S.L. Perceived Barriers to Adherence to Hemodialysis Dietary Recommendations. Clin. Nurs. Res. 2018. [CrossRef] [PubMed]

53. Alp Ikizler, T.; Flakoll, P.J.; Parker, R.A.; Hakim, R.M. Amino acid and albumin losses during hemodialysis. Kidney Int. 1994, 46, 830-837. [CrossRef] [PubMed]

54. Yokomatsu, A.; Fujikawa, T.; Toya, Y.; Shino-Kakimoto, M.; Itoh, Y.; Mitsuhashi, H.; Tamura, K.; Hirawa, N.; Yasuda, G.; Umemura, S. Loss of amino acids into dialysate during hemodialysis using hydrophilic and 
nonhydrophilic polyester-polymer alloy and polyacrylonitrile membrane dialyzers. Ther. Apher. Dial. 2014, 18, 340-346. [CrossRef]

55. Navarro, J.F.; Marcen, R.; Teruel, J.L.; Martin del Rio, R.; Gamez, C.; Mora, C.; Ortuno, J. Effect of different membranes on amino-acid losses during haemodialysis. Nephrol. Dial. Transplant. 1998, 13, 113-117. [CrossRef]

56. Wolfson, M.; Jones, M.R.; Kopple, J.D. Amino acid losses during hemodialysis with infusion of amino acids and glucose. Kidney Int. 1982, 21, 500-506. [CrossRef]

57. Hendriks, F.K.; Smeets, J.S.J.; Broers, N.J.H.; Van Kranenburg, J.M.X.; Sande, F.M.; Kooman, J.P.; Van Loon, L.J.C. Amino acid loss during hemodialysis in end-stage renal disease patients. Clin. Nutr. 2018, 37, S96. [CrossRef]

58. Pupim, L.B.; Majchrzak, K.M.; Flakoll, P.J.; Ikizler, T.A. Intradialytic oral nutrition improves protein homeostasis in chronic hemodialysis patients with deranged nutritional status. J. Am. Soc. Nephrol. 2006, 17, 3149-3157. [CrossRef]

59. Pupim, L.B.; Flakoll, P.J.; Brouillette, J.R.; Levenhagen, D.K.; Hakim, R.M.; Ikizler, T.A. Intradialytic parenteral nutrition improves protein and energy homeostasis in chronic hemodialysis patients. J. Clin. Investig. 2002, 110, 483-492. [CrossRef]

60. Frontera, W.R.; Ochala, J. Skeletal muscle: A brief review of structure and function. Calcif. Tissue Int. 2015, 96, 183-195. [CrossRef]

61. Raj, D.S.; Adeniyi, O.; Dominic, E.A.; Boivin, M.A.; McClelland, S.; Tzamaloukas, A.H.; Morgan, N.; Gonzales, L.; Wolfe, R.; Ferrando, A. Amino acid repletion does not decrease muscle protein catabolism during hemodialysis. Am. J. Physiol. Endocrinol. Metab. 2007, 292, E1534-E1542. [CrossRef] [PubMed]

62. Lim, V.S.; Ikizler, T.A.; Raj, D.S.; Flanigan, M.J. Does hemodialysis increase protein breakdown? Dissociation between whole-body amino acid turnover and regional muscle kinetics. J. Am. Soc. Nephrol. 2005, 16, 862-868. [CrossRef] [PubMed]

63. Ikizler, T.A.; Cano, N.J.; Franch, H.; Fouque, D.; Himmelfarb, J.; Kalantar-Zadeh, K.; Kuhlmann, M.K.; Stenvinkel, P.; TerWee, P.; Teta, D.; et al. Prevention and treatment of protein energy wasting in chronic kidney disease patients: A consensus statement by the International Society of Renal Nutrition and Metabolism. Kidney Int. 2013, 84, 1096-1107. [CrossRef] [PubMed]

64. Kalantar-Zadeh, K.; Ikizler, T.A. Let them eat during dialysis: An overlooked opportunity to improve outcomes in maintenance hemodialysis patients. J. Ren. Nutr. 2013, 23, 157-163. [CrossRef]

65. Kistler, B.M.; Benner, D.; Burrowes, J.D.; Campbell, K.L.; Fouque, D.; Garibotto, G.; Kopple, J.D.; Kovesdy, C.P.; Rhee, C.M.; Steiber, A.; et al. Eating During Hemodialysis Treatment: A Consensus Statement from the International Society of Renal Nutrition and Metabolism. J. Ren. Nutr. 2018, 28, 4-12. [CrossRef] [PubMed]

66. Sabatino, A.; Regolisti, G.; Karupaiah, T.; Sahathevan, S.; Sadu Singh, B.K.; Khor, B.H.; Salhab, N.; Karavetian, M.; Cupisti, A.; Fiaccadori, E. Protein-energy wasting and nutritional supplementation in patients with end-stage renal disease on hemodialysis. Clin. Nutr. 2017, 36, 663-671. [CrossRef]

67. Veeneman, J.M.; Kingma, H.A.; Boer, T.S.; Stellaard, F.; De Jong, P.E.; Reijngoud, D.J.; Huisman, R.M. Protein intake during hemodialysis maintains a positive whole body protein balance in chronic hemodialysis patients. Am. J. Physiol. Endocrinol. Metab. 2003, 284, E954-E965. [CrossRef]

68. Sundell, M.B.; Cavanaugh, K.L.; Wu, P.; Shintani, A.; Hakim, R.M.; Ikizler, T.A. Oral protein supplementation alone improves anabolism in a dose-dependent manner in chronic hemodialysis patients. J. Ren. Nutr. 2009, 19, 412-421. [CrossRef]

69. Dong, J.; Sundell, M.B.; Pupim, L.B.; Wu, P.; Shintani, A.; Ikizler, T.A. The effect of resistance exercise to augment long-term benefits of intradialytic oral nutritional supplementation in chronic hemodialysis patients. J. Ren. Nutr. 2011, 21, 149-159. [CrossRef]

70. Weiner, D.E.; Tighiouart, H.; Ladik, V.; Meyer, K.B.; Zager, P.G.; Johnson, D.S. Oral intradialytic nutritional supplement use and mortality in hemodialysis patients. Am. J. Kidney Dis. 2014, 63, 276-285. [CrossRef]

71. Tomayko, E.J.; Kistler, B.M.; Fitschen, P.J.; Wilund, K.R. Intradialytic protein supplementation reduces inflammation and improves physical function in maintenance hemodialysis patients. J. Ren. Nutr. 2015, 25, 276-283. [CrossRef] [PubMed]

72. Kalantar-Zadeh, K.; Gutekunst, L.; Mehrotra, R.; Kovesdy, C.P.; Bross, R.; Shinaberger, C.S.; Noori, N.; Hirschberg, R.; Benner, D.; Nissenson, A.R.; et al. Understanding sources of dietary phosphorus in the 
treatment of patients with chronic kidney disease. Clin. J. Am. Soc. Nephrol. 2010, 5, 519-530. [CrossRef] [PubMed]

73. Eloot, S.; Van Biesen, W.; Glorieux, G.; Neirynck, N.; Dhondt, A.; Vanholder, R. Does the adequacy parameter $\mathrm{Kt} / \mathrm{V}$ (urea) reflect uremic toxin concentrations in hemodialysis patients? PLOS ONE 2013, 8, e76838. [CrossRef] [PubMed]

74. Fuchs, C.J.; Hermans, W.J.H.; Holwerda, A.M.; Smeets, J.S.J.; Senden, J.M.; van Kranenburg, J.; Gijsen, A.P.; Wodzig, W.K.H.W.; Schierbeek, H.; Verdijk, L.B.; et al. Branched-chain amino acid and branched-chain ketoacid ingestion increases muscle protein synthesis rates in vivo in older adults: A double-blind, randomized trial. Am. J. Clin. Nutr. 2019, 110, 862-872. [CrossRef] [PubMed]

75. Shah, A.P.; Kalantar-Zadeh, K.; Kopple, J.D. Is there a role for ketoacid supplements in the management of CKD? Am. J. Kidney Dis. 2015, 65, 659-673. [CrossRef] [PubMed]

76. Phillips, S.M.; Tipton, K.D.; Aarsland, A.; Wolf, S.E.; Wolfe, R.R. Mixed muscle protein synthesis and breakdown after resistance exercise in humans. Am. J. Physiol. 1997, 273, E99-E107. [CrossRef]

77. Biolo, G.; Maggi, S.P.; Williams, B.D.; Tipton, K.D.; Wolfe, R.R. Increased rates of muscle protein turnover and amino acid transport after resistance exercise in humans. Am. J. Physiol. 1995, 268, E514-E520. [CrossRef]

78. Burd, N.A.; West, D.W.; Moore, D.R.; Atherton, P.J.; Staples, A.W.; Prior, T.; Tang, J.E.; Rennie, M.J.; Baker, S.K.; Phillips, S.M. Enhanced amino acid sensitivity of myofibrillar protein synthesis persists for up to $24 \mathrm{~h}$ after resistance exercise in young men. J. Nutr. 2011, 141, 568-573. [CrossRef]

79. Trommelen, J.; Holwerda, A.M.; Kouw, I.W.; Langer, H.; Halson, S.L.; Rollo, I.; Verdijk, L.B.; LJ, V.A.N.L. Resistance Exercise Augments Postprandial Overnight Muscle Protein Synthesis Rates. Med. Sci. Sports Exerc. 2016, 48, 2517-2525. [CrossRef]

80. Pennings, B.; Koopman, R.; Beelen, M.; Senden, J.M.; Saris, W.H.; van Loon, L.J. Exercising before protein intake allows for greater use of dietary protein-derived amino acids for de novo muscle protein synthesis in both young and elderly men. Am. J. Clin. Nutr. 2011, 93, 322-331. [CrossRef]

81. Holwerda, A.M.; Kouw, I.W.; Trommelen, J.; Halson, S.L.; Wodzig, W.K.; Verdijk, L.B.; van Loon, L.J. Physical Activity Performed in the Evening Increases the Overnight Muscle Protein Synthetic Response to Presleep Protein Ingestion in Older Men. J. Nutr. 2016, 146, 1307-1314. [CrossRef] [PubMed]

82. Glover, E.I.; Phillips, S.M.; Oates, B.R.; Tang, J.E.; Tarnopolsky, M.A.; Selby, A.; Smith, K.; Rennie, M.J. Immobilization induces anabolic resistance in human myofibrillar protein synthesis with low and high dose amino acid infusion. J. Physiol. 2008, 586, 6049-6061. [CrossRef] [PubMed]

83. Wall, B.T.; Dirks, M.L.; Snijders, T.; van Dijk, J.W.; Fritsch, M.; Verdijk, L.B.; van Loon, L.J. Short-term muscle disuse lowers myofibrillar protein synthesis rates and induces anabolic resistance to protein ingestion. Am. J. Physiol. Endocrinol. Metab. 2016, 310, E137-E147. [CrossRef] [PubMed]

84. Breen, L.; Stokes, K.A.; Churchward-Venne, T.A.; Moore, D.R.; Baker, S.K.; Smith, K.; Atherton, P.J.; Phillips, S.M. Two weeks of reduced activity decreases leg lean mass and induces "anabolic resistance" of myofibrillar protein synthesis in healthy elderly. J. Clin. Endocrinol. Metab. 2013, 98, 2604-2612. [CrossRef] [PubMed]

85. Dideriksen, K.; Reitelseder, S.; Holm, L. Influence of amino acids, dietary protein, and physical activity on muscle mass development in humans. Nutrients 2013, 5, 852-876. [CrossRef] [PubMed]

86. Holwerda, A.M.; Paulussen, K.J.M.; Overkamp, M.; Smeets, J.S.J.; Gijsen, A.P.; Goessens, J.P.B.; Verdijk, L.B.; van Loon, L.J.C. Daily resistance-type exercise stimulates muscle protein synthesis in vivo in young men. J. Appl. Physiol. (1985) 2018, 124, 66-75. [CrossRef] [PubMed]

87. Shad, B.J.; Thompson, J.L.; Holwerda, A.M.; Stocks, B.; Elhassan, Y.S.; Philp, A.; LJC, V.A.N.L.; Wallis, G.A. One Week of Step Reduction Lowers Myofibrillar Protein Synthesis Rates in Young Men. Med. Sci. Sports Exerc. 2019, 51, 2125-2134. [CrossRef]

88. Peterson, M.J.; Giuliani, C.; Morey, M.C.; Pieper, C.F.; Evenson, K.R.; Mercer, V.; Cohen, H.J.; Visser, M.; Brach, J.S.; Kritchevsky, S.B.; et al. Physical activity as a preventative factor for frailty: The health, aging, and body composition study. J. Gerontol. Ser. A Biol. Sci. Med. Sci. 2009, 64, 61-68. [CrossRef]

89. Zampieri, S.; Pietrangelo, L.; Loefler, S.; Fruhmann, H.; Vogelauer, M.; Burggraf, S.; Pond, A.; Grim-Stieger, M.; Cvecka, J.; Sedliak, M.; et al. Lifelong physical exercise delays age-associated skeletal muscle decline. J. Gerontol. Ser. A Biol. Sci. Med. Sci. 2015, 70, 163-173. [CrossRef] 
90. Dirks, M.L.; Wall, B.T.; van de Valk, B.; Holloway, T.M.; Holloway, G.P.; Chabowski, A.; Goossens, G.H.; van Loon, L.J. One Week of Bed Rest Leads to Substantial Muscle Atrophy and Induces Whole-Body Insulin Resistance in the Absence of Skeletal Muscle Lipid Accumulation. Diabetes 2016, 65, 2862-2875. [CrossRef]

91. Dirks, M.L.; Wall, B.T.; Nilwik, R.; Weerts, D.H.; Verdijk, L.B.; van Loon, L.J. Skeletal muscle disuse atrophy is not attenuated by dietary protein supplementation in healthy older men. J. Nutr. 2014, 144, 1196-1203. [CrossRef] [PubMed]

92. Piercy, K.L.; Troiano, R.P.; Ballard, R.M.; Carlson, S.A.; Fulton, J.E.; Galuska, D.A.; George, S.M.; Olson, R.D. The Physical Activity Guidelines for Americans. JAMA 2018, 320, 2020-2028. [CrossRef] [PubMed]

93. Ashby, D.; Borman, N.; Burton, J.; Corbett, R.; Davenport, A.; Farrington, K.; Flowers, K.; Fotheringham, J.; Andrea Fox, R.N.; Franklin, G.; et al. Renal Association Clinical Practice Guideline on Haemodialysis. BMC Nephrol. 2019, 20, 379. [CrossRef] [PubMed]

94. Matsuzawa, R.; Roshanravan, B.; Shimoda, T.; Mamorita, N.; Yoneki, K.; Harada, M.; Watanabe, T.; Yoshida, A.; Takeuchi, Y.; Matsunaga, A. Physical Activity Dose for Hemodialysis Patients: Where to Begin? Results from a Prospective Cohort Study. J. Ren. Nutr. 2018, 28, 45-53. [CrossRef]

95. Broers, N.J.H.; Martens, R.J.H.; Cornelis, T.; van der Sande, F.M.; Diederen, N.M.P.; Hermans, M.M.H.; Wirtz, J.; Stifft, F.; Konings, C.; Dejagere, T.; et al. Physical Activity in End-Stage Renal Disease Patients: The Effects of Starting Dialysis in the First 6 Months after the Transition Period. Nephron 2017, 137, 47-56. [CrossRef]

96. Tentori, F.; Elder, S.J.; Thumma, J.; Pisoni, R.L.; Bommer, J.; Fissell, R.B.; Fukuhara, S.; Jadoul, M.; Keen, M.L.; Saran, R.; et al. Physical exercise among participants in the Dialysis Outcomes and Practice Patterns Study (DOPPS): Correlates and associated outcomes. Nephrol. Dial. Transpl. 2010, 25, 3050-3062. [CrossRef]

97. Da Costa Rosa, C.S.; Nishimoto, D.Y.; Freitas Junior, I.F.; Ciolac, E.G.; Monteiro, H.L. Factors Associated with Levels of Physical Activity in Chronic Kidney Disease Patients Undergoing Hemodialysis: The Role of Dialysis Versus Nondialysis Day. J. Phys. Act. Health 2017, 14, 726-732. [CrossRef]

98. Gomes, E.P.; Reboredo, M.M.; Carvalho, E.V.; Teixeira, D.R.; Carvalho, L.F.; Filho, G.F.; de Oliveira, J.C.; Sanders-Pinheiro, H.; Chebli, J.M.; de Paula, R.B.; et al. Physical Activity in Hemodialysis Patients Measured by Triaxial Accelerometer. Biomed. Res. Int. 2015, 2015, 645645. [CrossRef] [PubMed]

99. Clarkson, M.J.; Bennett, P.N.; Fraser, S.F.; Warmington, S.A. Exercise interventions for improving objective physical function in patients with end-stage kidney disease on dialysis: A systematic review and meta-analysis. Am. J. Physiol. Ren. Physiol. 2019, 316, F856-F872. [CrossRef]

100. Koh, K.P.; Fassett, R.G.; Sharman, J.E.; Coombes, J.S.; Williams, A.D. Effect of intradialytic versus home-based aerobic exercise training on physical function and vascular parameters in hemodialysis patients: A randomized pilot study. Am. J. Kidney Dis. 2010, 55, 88-99. [CrossRef]

101. Salhab, N.; Karavetian, M.; Kooman, J.; Fiaccadori, E.; El Khoury, C.F. Effects of intradialytic aerobic exercise on hemodialysis patients: A systematic review and meta-analysis. J. Nephrol. 2019. [CrossRef] [PubMed]

102. Anding, K.; Bar, T.; Trojniak-Hennig, J.; Kuchinke, S.; Krause, R.; Rost, J.M.; Halle, M. A structured exercise programme during haemodialysis for patients with chronic kidney disease: Clinical benefit and long-term adherence. BMJ Open 2015, 5, e008709. [CrossRef] [PubMed]

103. Campbell, W.W.; Crim, M.C.; Young, V.R.; Evans, W.J. Increased energy requirements and changes in body composition with resistance training in older adults. Am. J. Clin. Nutr. 1994, 60, 167-175. [CrossRef] [PubMed]

104. Churchward-Venne, T.A.; Tieland, M.; Verdijk, L.B.; Leenders, M.; Dirks, M.L.; de Groot, L.C.; van Loon, L.J. There Are No Nonresponders to Resistance-Type Exercise Training in Older Men and Women. J. Am. Med. Dir. Assoc. 2015, 16, 400-411. [CrossRef]

105. Snijders, T.; Leenders, M.; de Groot, L.; van Loon, L.J.C.; Verdijk, L.B. Muscle mass and strength gains following 6months of resistance type exercise training are only partly preserved within one year with autonomous exercise continuation in older adults. Exp. Gerontol. 2019, 121, 71-78. [CrossRef]

106. Majchrzak, K.M.; Pupim, L.B.; Flakoll, P.J.; Ikizler, T.A. Resistance exercise augments the acute anabolic effects of intradialytic oral nutritional supplementation. Nephrol. Dial. Transplant. 2008, 23, 1362-1369. [CrossRef]

107. Bessa, B.; de Oliveira Leal, V.; Moraes, C.; Barboza, J.; Fouque, D.; Mafra, D. Resistance training in hemodialysis patients: A review. Rehabil. Nurs. 2015, 40, 111-126. [CrossRef]

108. Saitoh, M.; Ogawa, M.; Dos Santos, M.R.; Kondo, H.; Suga, K.; Itoh, H.; Tabata, Y. Effects of Intradialytic Resistance Exercise on Protein Energy Wasting, Physical Performance and Physical Activity in Ambulatory 
Patients on Dialysis: A Single-Center Preliminary Study in a Japanese Dialysis Facility. Ther. Apher. Dial. 2016, 20, 632-638. [CrossRef]

109. Gomes Neto, M.; de Lacerda, F.F.R.; Lopes, A.A.; Martinez, B.P.; Saquetto, M.B. Intradialytic exercise training modalities on physical functioning and health-related quality of life in patients undergoing maintenance hemodialysis: Systematic review and meta-analysis. Clin. Rehabil. 2018, 32, 1189-1202. [CrossRef]

110. Salhab, N.; Alrukhaimi, M.; Kooman, J.; Fiaccadori, E.; Aljubori, H.; Rizk, R.; Karavetian, M. Effect of Intradialytic Exercise on Hyperphosphatemia and Malnutrition. Nutrients 2019, 11, 2464. [CrossRef]

111. Chan, D.; Cheema, B.S. Progressive Resistance Training in End-Stage Renal Disease: Systematic Review. Am. J. Nephrol. 2016, 44, 32-45. [CrossRef] [PubMed]

112. Cheema, B.; Abas, H.; Smith, B.; O'Sullivan, A.; Chan, M.; Patwardhan, A.; Kelly, J.; Gillin, A.; Pang, G.; Lloyd, B.; et al. Progressive exercise for anabolism in kidney disease (PEAK): A randomized, controlled trial of resistance training during hemodialysis. J. Am. Soc. Nephrol. 2007, 18, 1594-1601. [CrossRef] [PubMed]

113. Kopple, J.D.; Wang, H.; Casaburi, R.; Fournier, M.; Lewis, M.I.; Taylor, W.; Storer, T.W. Exercise in maintenance hemodialysis patients induces transcriptional changes in genes favoring anabolic muscle. J. Am. Soc. Nephrol. 2007, 18, 2975-2986. [CrossRef] [PubMed]

114. Kirkman, D.L.; Mullins, P.; Junglee, N.A.; Kumwenda, M.; Jibani, M.M.; Macdonald, J.H. Anabolic exercise in haemodialysis patients: A randomised controlled pilot study. J. Cachexia Sarcopenia Muscle 2014, 5, $199-207$. [CrossRef]

115. Van den Ham, E.C.; Kooman, J.P.; Schols, A.M.; Nieman, F.H.; Does, J.D.; Akkermans, M.A.; Janssen, P.P.; Gosker, H.R.; Ward, K.A.; MacDonald, J.H.; et al. The functional, metabolic, and anabolic responses to exercise training in renal transplant and hemodialysis patients. Transplantation 2007, 83, 1059-1068. [CrossRef]

116. Martin-Alemany, G.; Valdez-Ortiz, R.; Olvera-Soto, G.; Gomez-Guerrero, I.; Aguire-Esquivel, G.; Cantu-Quintanilla, G.; Lopez-Alvarenga, J.C.; Miranda-Alatriste, P.; Espinosa-Cuevas, A. The effects of resistance exercise and oral nutritional supplementation during hemodialysis on indicators of nutritional status and quality of life. Nephrol. Dial. Transplant. 2016, 31, 1712-1720. [CrossRef]

117. Molsted, S.; Harrison, A.P.; Eidemak, I.; Andersen, J.L. The effects of high-load strength training with proteinor nonprotein-containing nutritional supplementation in patients undergoing dialysis. J. Ren. Nutr. 2013, 23, 132-140. [CrossRef]

118. Martin-Alemany, G.; Espinosa-Cuevas, M.L.A.; Perez-Navarro, M.; Wilund, K.R.; Miranda-Alatriste, P.; Cortes-Perez, M.; Garcia-Villalobos, G.; Gomez-Guerrero, I.; Cantu-Quintanilla, G.; Ramirez-Mendoza, M.; et al. Effect of Oral Nutritional Supplementation With and Without Exercise on Nutritional Status and Physical Function of Adult Hemodialysis Patients: A Parallel Controlled Clinical Trial (AVANTE-HEMO Study). J. Ren. Nutr. 2019. [CrossRef]

119. Molsted, S.; Bjorkman, A.S.D.; Lundstrom, L.H. Effects of strength training to patients undergoing dialysis: A systematic review. Dan. Med. J. 2019, 66, A5526.

120. Witard, O.C.; Wardle, S.L.; Macnaughton, L.S.; Hodgson, A.B.; Tipton, K.D. Protein Considerations for Optimising Skeletal Muscle Mass in Healthy Young and Older Adults. Nutrients 2016, 8, 181. [CrossRef]

121. Trommelen, J.; Betz, M.W.; van Loon, L.J.C. The Muscle Protein Synthetic Response to Meal Ingestion Following Resistance-Type Exercise. Sports Med. 2019, 49, 185-197. [CrossRef] [PubMed]

122. Oquendo, L.G.; Asencio, J.M.M.; de Las Nieves, C.B. Contributing factors for therapeutic diet adherence in patients receiving haemodialysis treatment: An integrative review. J. Clin. Nurs. 2017, 26, 3893-3905. [CrossRef] [PubMed]

(C) 2019 by the authors. Licensee MDPI, Basel, Switzerland. This article is an open access article distributed under the terms and conditions of the Creative Commons Attribution (CC BY) license (http://creativecommons.org/licenses/by/4.0/). 